\title{
INFLUENCE OF COOPERATIVE SOCIETIES ON THE WELLBEING OF STAFF AMONG UNIVERSITIES IN EKITI STATE, NIGERIA
}

\section{Ajayi Ibidolapo Ezekiel ${ }^{1}$ and Chilokwu Innocent Darlington Okechukwu ${ }^{2}$}

${ }^{1}$ Ekiti State University, Department of Finance (Cooperative and Rural Development Studies)

${ }^{2}$ Nnamdi Azikwe University, Department of Cooperative Economics and Management

Cite this article:

Ajayi I.E., Chilokwu I.D.O. (2021), Influence of

Cooperative Societies on the Wellbeing of Staff Among Universities in Ekiti State, Nigeria. British Journal of Management and Marketing Studies 4(4), 21-33. DOI: 10.52589/BJMMS-

M2XEENAI.

\section{Manuscript History}

Received: 29 Sept 2021

Accepted: 19 Oct 2021

Published: 28 Oct 2021

Copyright $\odot 2020$ The Author(s). This is an Open Access article distributed under the terms of Creative Commons AttributionNonCommercial-NoDerivatives 4.0 International (CC BY-NC-ND

4.0 ), which permits anyone to share, use, reproduce and redistribute in any medium, provided the original author and source are credited.
ABSTRACT: The study examined the effect of cooperative societies on the well-being of staff among Universities in Ekiti State, Nigeria. The specific objectives are to access the effects of educational loans on the well-being of the staff, investigate the effect of land acquisition on the well-being of the staff and determine the effect of commodity purchase (household Asset) on the well-being of staff among Universities in Ekiti State, Nigeria. The total population of this study is three thousand two hundred and five $(3,205)$ comprising the entire cooperators in the three Universities in Ekiti State, namely Federal University, Oye Ekiti, Ekiti State University, Ado Ekiti and Afe Babalola University, Ado Ekiti. The study employed a stratified random sampling technique for selecting a sample size of 355 respondents which are further divided among cooperators in the three Universities in Ekiti State. Data gathered were analysed using frequency tables and multiple regression analysis to achieve the objectives of the study. The results showed that cooperative societies significantly affect the well-being of staff among Universities in Ekiti State, Nigeria. Specifically, the sub-variables of the cooperative societies were considered significant in the order of educational loan $(p=0.000)$, land acquisition $(p=0.000)$ and commodity purchase (household asset) $(p=0.000)$. This implies that cooperative societies have an effect on the well-being of staff among Universities in Ekiti State. The study concluded that access to educational loans, land acquisition and commodity purchases (household assets) have a significant positive relationship with the well-being of staff among Universities in Ekiti State, Nigeria at a 5\% level of significance.

KEYWORDS: Cooperative Societies, Wellbeing, Staff, Educational Loans, Nigeria 


\section{INTRODUCTION}

\section{Background to the Study}

One of the importance of cooperative societies is in their effectiveness in empowering people to exercise control and improve their standard of living by providing an exclusive means for achieving one or more economic goals in an increasingly competitive global economy (Ajayi, Dada \& Obisesan, 2021). Cooperative societies play a crucial role in assisting individuals or groups of persons to achieve a common goal easily and in a more effective way. Generally, cooperative provides an economic boost to members (Akerele \& Adekunmbi, 2018) and are established to satisfy people's mutual needs. The belief that a group of people can attain goals that none of them can achieve individually has been the drive for the consolidation of the influence of cooperatives in society (Ajayi et al., 2021).

According to Nada, Jana and Veronika (2015), well-being centres more on material consumption and luxury goods. The term "well-being centres" is used for the expression of conditions in which a person or a nation lives, and which they also help to create. From the economic perspective, the standard of living is considered in material terms, mostly income, consumption and unemployment while gross domestic product per capita is most generally used for international assessment of universal standards of living. In an attempt to increase the standard of living, members themselves through their respective cooperative societies are also striving in more important ways to improve their wellbeing. This is achieved through the pooling of their resources to form cooperatives and operate the same for the benefit of members. Indicators of the well-being among the staff of cooperative societies usually include but are not limited to the creation of wealth (asset acquisition (household asset), education, housing) and employment but also in terms of environment, physical and mental health, recreation and leisure time, and social belonging that are secondary indicators of measuring standard of living. Also, the quality of life as it relates to the standard of living is tightly related to such issues as freedom, human rights, and happiness (Streimikiene, 2015).

Dogarawa, (2005) opines that cooperative societies have the capacity to develop and improve the socio-economic conditions of their members. Because of this, there has been a considerable expectation from cooperators of these cooperative societies to achieve social economic goals and also spur development, thereby increasing their standard of living. It is against this background that various institutions have grouped themselves for greater efficiency and effectiveness through cooperation.

\section{Statement of the Problem}

In present-day Nigeria, the entire labour force is encompassed by a common character of dissatisfaction, and the Nigerian university staff is included in the wide-ranging situation of discontent and aggravation. Recently, there has been a spate of industrial conflicts in Nigerian public universities arising from the failure of the management to re-assess conditions of service to improve the standard of living in the face of progressively higher costs of living (Fapohunda, 2015) while the study of Odey, Omang, and Agba (2018) revealed that despite the progressively higher cost of living, cooperative societies are crucial for elevating the standard of living of workers as regards to medical bills, purchase cheap plots of land, build houses, pay house rents, purchase of luxury goods and children school fees. Cooperative societies have over time, remained in a state of change. In practically all parts of the world, especially Nigeria, 
cooperatives have suffered several crises that have negatively influenced their role in the improvement of well-being (Ajayi et al., 2021).

In spite of the large budgetary allocation directed towards the implementation of various programmes targeted at improving the standard of living of citizens, Orji (2015) argues that the standard of living of a significant proportion of the country's workforce has been unpleasant and terrible. Orji (2015) further reveals that indicators for improvement in the standard of living of citizens include but are not limited to better quality in education, asset creation (luxury items such as home appliances, cars etc), housing loans, electricity. The Nigerian Bureau of Stastitics (2019) buttress the position of Orji (2015) that over 40\% of the most populous African Nation (Nigeria) lived below its poverty line of $\mathrm{N17,430}(\$ 381.75)$ a year which has a negative implication on their standard of living.

While all these efforts are visible, there is little evidence to show that the well-being of workers has improved in Nigeria.

\section{Objectives of the Study}

The study pursues the following specific objectives:

i. access the effects of educational loan on the well-being of staff among universities in Ekiti State, Nigeria;

ii. investigate the effect of land acquisition on the well-being of staff among universities in Ekiti State, Nigeria;

iii. determine the effect of commodity purchase (household Asset) on the well-being of staff among universities in Ekiti State, Nigeria.

\section{LITERATURE REVIEW}

\section{Perception of Cooperative Societies}

Cooperative societies play essential roles from the development and socio-economic point of view in the Nigerian tertiary system. Members of cooperatives are steadily shifting from being uni-functional to multifunctional by joining other cooperative societies so as to increase their financial and non-financial strength as well as been able to meet the demand of the market force (Onah, 2014). An institutional cooperative society is a unique type of cooperative society that embraces both the associative component as well as the business component and are guided by the operations of the International Cooperative Alliance (ICA) in terms of values and principles of cooperation.

The motive is inducing individuals to join existing or to form new cooperatives that can originate in the economic-rational sphere and the sociological and psychological spheres. institutional cooperatives are primarily members (Academic and Non-Academic staff) of a university community who have come together to achieve some common commercial objectives more successfully than they could as individuals such as marketing their produce, purchasing luxurious assets, purchasing consumer goods for sale or supplying services such as storage or transport (Masuku, Masuku \& Muntangura, 2016). Unlike other forms of 
cooperative societies, the institutional cooperative society has contributed greatly to help enhance and self-sufficiency of members as regards to household products, facilitation of cooperative loans from both financial institutions (Banks) and non-bank financial institutions (institutional cooperatives) and encouraging democratic decision-making processes, leadership development and education. Addisu (2011) opines that institutional cooperative societies have a great potential to serve the needs of members better than other business types.

Institutional cooperative societies have been established to support members who are handicapped by their lack of negotiating power in the global economy. Institutional cooperatives have become more open to members of staff and are now relatively democratic and acceptable as a means of raising member's standard of living. Thus, institutional cooperatives have provided higher satisfactory services to members than what is obtainable in the financial sector of the economy. The actual constraint of institutional cooperative societies is limited to financial constraints. As a result, the majority of cooperators continue to rely on joining more than one cooperative society within their respective institutions (Tekeste, Muthyalu \& Azmera, 2014). The key factors that contribute to institutional cooperatives success include but are not limited to; leadership strength, number and members' participation, sufficient resources and above all, institutional management supports. The internal factors that would affect a cooperative's success are the ones that arise internally and these include members' commitment, members' participation, structural, communication and managerial factors. The external factors, considered essential in the success of a cooperative, include assistance that acts as motivation for members in a cooperative, external assistance, government policies, regulatory frameworks and market factors (Desalegn, 2019).

\section{Clarification of Wellbeing and Benefits}

Workers standard of living has existed in different forms and shapes in all organisations regardless of their size or structure. The emphasis on what constitutes the standard of living and how it should be administered to workers also varies with time and space. Workers' standard of living in a broad sense consists of workers insurance cover, education compensation, housing loan, asset creation, condition of services, working hours, vocation and other employment services (Odey et al., 2018). The study of Warr (2007) and Olaniyi, Osemene and Omotehinse (2013) opined that the standard of living of workers is a function of the state of employees' wellbeing, happiness, prosperity, and health. This is traceable to financial or non-financial compensation given to employees by the employers to supplement their wages. The purpose of agitation of a good standard of living by employees is to create a working healthy and congenial environment that promotes good health, high morale and productivity. They are direct and indirect valuables given to employees by management and other well-wishing bodies to boost workers commitment, satisfaction and efficiency. An improved standard of living denotes an increase in the social and economic activities of employers (Bhardwaj, 2012).

Odey et al., (2018) denote that standard of living can be grouped into statutory and nonstatutory. While statutory are those that can be provided by employers, non-statutory are those that can be gotten as a result of a better condition of service. Statutory standard of living includes medical benefits, occupational health services, gratuity, travelling facilities, and drinking water. Employees' medical benefits help in reducing the incidence of sickness among workers and enhance their productivity. Occupational health services help in protecting workers against health hazards arising from the work environment. This includes periodic 
medical checks and health education/enlightenment. Travelling welfare covers transportation to-and-from housing colony, etc. non-statutory standard of living includes housing, education, transport, recreation, cooperative stores, travel leave and uniforms (Peter, Jana, \& Alena, 2015).

The primary objective of agitating for a sustainable standard of living is to produce and encourage employee's happiness and productivity to work. Standard of living enables organisations to keep employee's motivation levels high and to retain their services. It encourages a healthy work environment by providing better physical and mental health for employees. It helps in raising the well-being of employees' families. It reduces turnover and helps in maintaining a stable labour force in a work organisation. It creates an efficient, loyal, and satisfied workforce in formal work organisations. This is because good welfare creates happiness among workers and stimulates their morale for higher productivity (Tammisetty, 2013). Standard of living enables employees to live comfortably and more satisfactory life. Workers welfare provides chain benefits to employees, organisations and society at large. At the individual level, workers welfare helps in improving the physical, mental, intellectual, and cultural aspirations of the employee.

\section{METHODOLOGY}

\section{Research Design}

The study adopted a cross-sectional survey research design. The design was considered appropriate for the study because the survey is concerned with describing, recording, analyzing and reporting conditions that exist or existed.

\section{Area of the Study}

The study was carried out in Ekiti State, Nigeria. Ekiti State is one of the six states in the SouthWest geopolitical zones of Nigeria. The states in the South-West geopolitical zone consist of Lagos, Ogun, Oyo, Ondo, Osun and Ekiti. Ekiti State covers 6,353 square kilometres.

\section{Population of the Study}

The population of the study is three thousand two hundred and five $(3,205)$, which makes up most of the entire cooperators in universities in Ekiti State.

\section{Sample Size Determination and Sampling Techniques}

\section{Sample Size Determination}

The statistical formula applied to determine the sample size from the population of the study as formulated by Taro Yamani (1967) is stated as follows: 


$$
\frac{N}{1+N(e)^{2}}
$$

Where $\mathrm{n}=$ sample size to be tested

$$
\begin{aligned}
& \mathrm{N}=\text { total population size } \\
& \mathrm{e}=\text { acceptable error term }(0.05)
\end{aligned}
$$

Therefore, the total sample size is calculated thus:

The sample size for institutional cooperators is:

$$
\frac{3205}{1+3205(0.05)^{2}}=355
$$

The total sample size is three hundred and fifty-five which are further divided among cooperators in the three universities in Ekiti State.

\section{Sampling Technique}

Taro Yamani (1967) model was used to calculate the sample size of each stratum as below:

$$
n=\frac{N_{i} n_{i}}{N}
$$

Where:

$\mathrm{n}=$ Number of respondents from each academic staff of universities in Ekiti State

$\mathrm{n}_{\mathrm{i}}=$ total sample size

$\mathrm{N}_{\mathrm{i}}=$ number in each group

$\mathrm{N}=$ population size of the study

Therefore,

Table 3.2: Ekiti State University, Ado Ekiti

\begin{tabular}{|l|l|l|}
\hline $\begin{array}{l}\text { S/ } \\
\mathbf{N}\end{array}$ & Cooperative Society & Sample size \\
\hline 1 & Academic Staff Cooperative & $\frac{(530)(356)}{3205}=59$ \\
\hline 2 & EKSU General Cooperative & $\frac{(1200)(356)}{3205}=132$ \\
\hline & Total & 191 \\
\hline
\end{tabular}

Source: Author's Computation 2021 
British Journal of Management and Marketing Studies

ISSN: 2689-5072

Volume 4, Issue 4, 2021 (pp. 21-33)

www.abjournals.org

Table 3.3: Federal University, Oye Ekiti

\begin{tabular}{|l|l|l|}
\hline $\begin{array}{l}\text { S/ } \\
\mathbf{N}\end{array}$ & Cooperative Society & Sample size \\
\hline 1 & Academic Staff Cooperative & $\frac{(98)(356)}{3205}=11$ \\
\hline 2 & EKSU General Cooperative & $\frac{(950)(356)}{3205}=106$ \\
\hline & Total & 117 \\
\hline
\end{tabular}

Source: Author's Computation 2021

Table 3.4: Afe Babalola University

\begin{tabular}{|l|l|l|}
\hline $\begin{array}{l}\text { S/ } \\
\mathbf{N}\end{array}$ & Cooperative Society & Sample size \\
\hline 1 & ABUAD General Cooperative & $\frac{(427)(356)}{3205}=47$ \\
\hline & Total & 47 \\
\hline
\end{tabular}

Source: Author's Computation 2021

From table 3.2, 3.3 and 3.4 the total number of respondents was three hundred and fifty-five (355)

\section{Model Specification}

Objective 1: Access the effects of educational loans on the well-being of staff among universities in Ekiti State, Nigeria;

$$
W S=\beta_{o}+\beta_{1} E L+\mu
$$

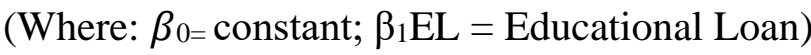

Objective 2: Investigate the effect of land acquisition on the well-being of staff among universities in Ekiti State, Nigeria;

$$
W S=\beta_{o}+\beta_{1} L A+\mu
$$

(Where: $\beta_{0=}$ constant; $\beta_{1} \mathrm{LA}=$ Land Acquisition)

Objective 3: Determine the effect of commodity purchase (household Asset) on the well-being of staff among universities in Ekiti State, Nigeria.

$$
W S=\beta_{o}+\beta_{1} C P+\mu
$$

(Where: $\beta_{0=}$ constant; $\beta_{1} \mathrm{CP}=$ Commodity Purchase) 


\section{DATA ANALYSIS AND DISCUSSION}

Objective 1: access the effects of educational loans on the well-being of staff among universities in Ekiti State, Nigeria;

To test this hypothesis, the respondents' scores on two variables of educational loan and wellbeing of staff among universities in Ekiti State, Nigeria were computed and subjected to simple regression analysis. From Table 4.4, the $\mathrm{R}$ (correlation Coefficient) gives a positive value of 0.934; this indicates that there is a strong and positive relationship between educational loans and the well-being of Staff among universities in Ekiti State.

The $\mathrm{R}^{2}$ is a portion of the total variation in the dependent variable that is explained by the variation in the independent variables. From the results obtained, $\mathrm{R}^{2}$ is equal to 0.873 , this implies that educational loan $87.3 \%$ variance in the well-being of the staff, this is further proven by the adjusted $\mathrm{R}^{2}$ that shows the goodness of fit of the model which gives a value of 0.873 , implying that when all errors are corrected and adjustments are made, the model can only account for $87.3 \%$ by the educational loan; while the remaining $12.7 \%$ are explained by the error term in the model in the surveyed of among universities in Ekiti State as shown in Table 4.4 .

The unstandardized beta co-efficient of educational loan is 0.826 with $\mathrm{t}=38.132$ and $(\mathrm{p}=0.000$ $<0.05$ ). These results showed that educational loans have an effect on the well-being of staff among universities in Ekiti State. This implies that the cooperative institution accepts monthly contributions from members placing them at an advantage when requesting for educational loan.

\section{Table 4.1: Educational Loan and Well-being of Staff}

\begin{tabular}{|l|l|l|l|l|}
\hline Variable & Coeff. & Std Error & t-value & Sig. \\
\hline Constant & 0.672 & 0.093 & 7.254 & 0.000 \\
\hline Educational Loan & 0.826 & 0.022 & 38.132 & 0.000 \\
\hline R & 0.934 & & & \\
\hline R Square & 0.873 & & & \\
\hline Adj. R Square & 0.873 & & & \\
\hline F Stat. & $1454.015(0.000)$ & & & \\
\hline
\end{tabular}

Dependent Variable: Wellbeing of Staff

Objective 2: investigate the effect of land acquisition on the well-being of staff among universities in Ekiti State, Nigeria;

To test this hypothesis, the respondents' scores on two variables of land acquisition and wellbeing of staff among universities in Ekiti State were computed and subjected to simple regression analysis. From Table 4.5, the $\mathrm{R}$ (correlation coefficient) gives a positive value of 0.937; this indicates that there is a strong and positive relationship between land acquisition and the well-being of Staff among universities in Ekiti State

The $\mathrm{R}^{2}$ is a portion of the total variation in the dependent variable that is explained by the variation in the independent variables. From the results obtained, $\mathrm{R}^{2}$ is equal to 0.877 , this 
suggests that land acquisition brought about $87.7 \%$ variance in the well-being of staff, this is further proven by the adjusted $\mathrm{R}^{2}$ that shows the goodness of fit of the model which gives a value of 0.877 , implying that when all errors are corrected and adjustments are made, the model can only account for $87.7 \%$ by land acquisition; while the remaining $12.3 \%$ are explained by the error term in the model in the surveyed of among universities in Ekiti State, Nigeria as shown in Table 4.5 .

The unstandardized beta co-efficient of land acquisition is 0.911 with $\mathrm{t}=38.831$ and $(\mathrm{p}=0.000$ $<0.05$ ). These results showed that land acquisition has an effect on the well-being of staff. This implies that the members acquiring land for housing purposes directly from cooperative societies reduce the financial burden on members because the repayment process by members on land acquisition through cooperative societies for housing purposes is easy without default.

Table 4.2: Land Acquisition and well-being of Staff among Universities in Ekiti State

\begin{tabular}{|l|l|l|l|l|}
\hline Variable & Coeff. & Std Error & t-value & Sig. \\
\hline Constant & 0.267 & 0.101 & 2.635 & 0.009 \\
\hline Land Acquisition & 0.911 & 0.023 & 38.831 & 0.000 \\
\hline R & 0.937 & & & \\
\hline R Square & 0.877 & & & \\
\hline Adj. R Square & 0.877 & & & \\
\hline F Stat. & $1507.827(0.000)$ & \multicolumn{3}{|l|}{} \\
\hline
\end{tabular}

Dependent Variable: Wellbeing of Staff

Objective 3: determine the effect of commodity purchase (household asset) on the well-being of staff among universities in Ekiti State, Nigeria.

To test this hypothesis, the respondents' scores on two variables of commodity purchase and the well-being of staff among universities in Ekiti State were computed and subjected to simple regression analysis. From Table 4.6, the $\mathrm{R}$ (correlation Coefficient) gives a positive value of 0.910 ; this indicates that there is a strong and positive relationship between community purchase and the well-being of staff among universities in Ekiti State.

The $\mathrm{R}^{2}$ is a portion of the total variation in the dependent variable that is explained by the variation in the independent variables. From the results obtained, $\mathrm{R}^{2}$ is equal to 0.829 , this implies that commodity purchase brought about $82.9 \%$ variance in the well-being of staff, this is further proven by the adjusted $\mathrm{R}^{2}$ that shows the goodness of fit of the model which gives a value of 0.828 , implying that when all errors are corrected and adjustments are made, the model can only account for $82.8 \%$ by commodity purchase; while the remaining $17.2 \%$ are explained by the error term in the model in the surveyed of among universities in Ekiti as shown in Table 4.6 .

The unstandardized beta co-efficient of community purchase is 0.795 with $\mathrm{t}=31.979$ and $(\mathrm{p}=$ $0.000<0.05$ ). These results showed that commodity purchase has a positive relationship with the well-being of the staff. This suggests that the interest rate charged by cooperative societies on commodities purchased is easily affordable compare to other financial institutions. 
Table 4.3: Commodity Purchase and Wellbeing of Staff among Universities in Ekiti State

\begin{tabular}{|l|l|l|l|l|}
\hline Variable & Coeff. & Std Error & t-value & Sig. \\
\hline Constant & 0.744 & 0.108 & 6.879 & 0.000 \\
\hline $\begin{array}{l}\text { Community } \\
\text { Purchase }\end{array}$ & 0.795 & 0.025 & 31.979 & 0.000 \\
\hline R & 0.910 & & & \\
\hline R Square & 0.829 & & & \\
\hline Adj. R Square & 0.828 & & & \\
\hline F Stat. & $1022.648(0.000)$ & & & \\
\hline
\end{tabular}

Dependent Variable: Wellbeing of Staff

\section{Cooperative Societies and Wellbeing of Staff among Universities in Ekiti State}

To test this hypothesis, the respondents' scores on four variables of cooperative societies (educational loan, land acquisition and community purchase) on the well-being of the staff were computed and subjected to multiple regression analysis. From Table 4.7, the R (correlation coefficient) gives a positive value of 0.910; this indicates that there is a strong and positive relationship between cooperative societies (educational loan, land acquisition and community purchase) on the well-being of staff among universities in Ekiti State, Nigeria.

The $\mathrm{R}^{2}$ is a portion of the total variation in the dependent variable that is explained by the variation in the independent variables. From the results obtained, $\mathrm{R}^{2}$ is equal to 0.944 , this suggests that cooperative societies (educational loan, land acquisition and community purchase) brought about $94.4 \%$ variance in the well-being of staff, this is further proven by the adjusted $\mathrm{R}^{2}$ that shows the goodness of fit of the model which gives a value of 0.828 , implying that when all errors are corrected and adjustments are made, the model can only account for $82.8 \%$ by staff corrective cooperative societies; while the remaining $17.2 \%$ are explained by the error term in the model in the surveyed among universities of Ekiti State as shown in Table 4.7.

The unstandardized beta co-efficient of educational loan is 0.305 with $\mathrm{t}=2.705$ and $(\mathrm{p}=0.007$ $<0.05$ ). This revealed that the monthly contribution of members places them at an advantage when requesting for educational loan.

The unstandardized beta co-efficient of land acquisition is 0.496 with $\mathrm{t}=5.749$ and $(\mathrm{p}=0.000$ $<0.05)$. These results showed that land acquisition has a positive relationship with the wellbeing of the staff. This suggests that when members acquired land, there is a minimal administrative charge when securing land for housing purposes through cooperative societies and is the most significant among the three variables under study.

The unstandardized beta co-efficient of community purchase is 0.087 with $\mathrm{t}=1.083$ and $(\mathrm{p}=$ $0.280>0.05$ ). These results showed that community purchase has a positive relationship with the well-being of the staff. This implies that the higher the contribution of cooperative societies of asset acquisition through cooperative societies. 
Table 4.4: Cooperative Societies and Well-being of Staff among Universities in Ekiti State

\begin{tabular}{|l|l|l|l|l|}
\hline Variable & Coeff. & Std Error & t-value & Sig. \\
\hline Constant & 0.379 & 0.100 & 3.789 & 0.000 \\
\hline Educational Loan & 0.305 & 0.113 & 2.705 & 0.007 \\
\hline Land Acquisition & 0.496 & 0.086 & 5.749 & 0.000 \\
\hline $\begin{array}{l}\text { Community } \\
\text { Purchase }\end{array}$ & 0.087 & 0.080 & 1.083 & 0.280 \\
\hline R & 0.944 & & & \\
\hline R Square & 0.891 & & & \\
\hline Adj. R Square & 0.889 & & & \\
\hline F Stat. & $569.227(0.000)$ & & & \\
\hline
\end{tabular}

Dependent Variable: Wellbeing of Staff

\section{Summary of Hypotheses}

\section{Hypothesis One}

From the discussion in objective one, and by p-value <.05, it showed that the null hypothesis i.e educational loan does not significantly affect the well-being of staff among universities in Ekiti state, therefore, the null hypothesis is rejected. Based on this, we accepted the alternative hypothesis that educational loan affects the well-being of staff among universities in Ekiti state.

\section{Hypothesis Two}

Here, the null hypothesis that land acquisition does not significantly affect the well-being of the staff was rejected and the alternative hypothesis accepted i.e land acquisition would significantly affect the well-being of staff among universities in Ekiti state.

\section{Hypothesis Three}

Lastly, in hypothesis three, the alternative hypothesis was accepted. That is, community purchase would significantly affect the well-being of staff among universities in Ekiti state, Nigeria.

\section{CONCLUSION AND RECOMMENDATIONS}

The study evaluates the influence of cooperative societies on the well-being of staff among universities in Ekiti state, Nigeria. The independent variable (cooperative societies) was proxied by access to educational loans, land acquisition and commodity purchase (household asset) while the well-being of the staff was measured by social well-being, cultural well-being and environmental well-being of staff served as the dependent variable. This study utilized primary data basically, which were extracted from the questionnaire distributed to 355 cooperators institutions in Ekiti state. With the aid of Statistical Package for Social Sciences (SPSS) version 20, descriptive statistics included the frequency and percentage count while inferential statistics using multiple regression analysis were employed. 
On the premise of these study findings, the following recommendations were made:

i. Based on the positive relationship that exists between them, land acquisitions have a positive effect on the well-being of staff, Tertiary institutions should, as a matter of urgency and priority, review the cooperative society laws and regulations of the university from time to time in order to meet the desired needs and aspirations of the cooperatives.

ii. National University Commission should establish cooperative units under the various tertiary institutions which will work hand-in-hand with the universities' agencies concerned with cooperative activities.

iii. It is also advisable that government should be engaged in a wide and large-scale campaign in order to educate members and non-members of cooperatives about the contributions of cooperatives to the social and economic well-being of the common man.

iv. Members should be enlightened on the use of credit and also on the sources from which they can obtain loans and the terms of the available loans.

\section{REFERENCES}

Addisu, W. (2011). The role of multipurpose farmers cooperatives in the supply chain of wheat in Gedeb-Hasasa Woreda, Oromia regional state. Unpublished masters' thesis, Department of Cooperative Studies, Mekelle University.

Ajayi, I. E., Dada, S. O. \& Obisesan, O. G. (2021). Nexus between cooperative society and poverty alleviation in Ekiti State. International Journal of Economics, Business and Management Research, 5(3), 317-328.

Akerele, E. O. \& Adekunmbi, S. A. (2018). Impacts of cooperative thrift and credit facilities on members' business output in Ogun State, Nigeria. Journal of Sustainable Agriculture Research, 7(3), 28-39.

Desalegn, F. (2019). The role of multi-purpose cooperatives in the economic development in Ethiopia, The case of Lalo-Assabi District. Research on Humanities and Social Sciences, 9(21), 18-31.

Dogarawa, A. B. (2005). The Role of Cooperative Societies in Economic Development. MPRA Paper No. 23161. Available online at: http://mpra.ub.unimuenchen.de/23161. Retrieved on: August 27, 2012.

Fapohunda, M. T. (2015). Dimensions of University academic staff performance appraisal in selected public universities in Nigeria. Journal of Global Economics, Management and Business Research, 3(3), 139-147.

Masuku, T. A., Masuku M. B., \& Muntangura J. T. B. (2016). Performance of multi-purpose cooperatives in Shiselweni Region of Swaziland. International journal of sustainable Agricultural Research, 3(4), 58-71.

Nada, B., Jana S., \& Veronika A. (2015). Evaluating living standard indicators. Journal of Law and Economics Review, 6(3), 175-188.

Odey, S., Omang, T. A., \& Agba, A. M. (2018). Labour union cooperative organizations and workers' welfare in Nigeria. International Journal of Humanities and Social Science Invention, 7(2), 49-57. 
Onah, O. G. (2014). Performance of Farmers' Multipurpose Cooperative Societies In Enugu North Agricultural Zone Of Enugu State, Nigeria. Unpublished Thesis University of Nsukka.

Orji, J. I. (2015). An Assessment of Poverty Reduction Programmes in Nigeria as a Development Strategy, 1970-2005. Ph.D. Thesis, Unpublished. The St. Clements University, Turks and Caicos Island.

Peter, M., Jana, P., \& Alena, D. (2015). Standard of living as a factor of Countries competitiveness. Journal of Procedia Economics and Finance 34(1), 500 - 507.

Streimikiene, D. (2015). Quality of life and housing. International Journal of Information and Education Technology, 5(2), 140-145.

Tekeste, B. L., Muthyalu, M., \& Azmera, G. (2014). A study on the financial performance of multipurpose cooperative unions Of Tigrai Region, Ethiopia. International Journal of Community and Cooperative Studies, 1(1), 15-26. 